\title{
METHODOLOGY OF VISUAL ART LOCALIZATION IN PUBLIC SPACES ON EXAMPLE OF POZNAN CITY
}

\author{
Anna Januchta-Szostak \\ Institute of Architecture and Physical Planning, Faculty of Architecture, \\ Poznan University of Technology, ul. Nieszawska 13C, 61-021 Poznań, Poland \\ E-mail: Anna.Januchta-Szostak@put.poznan.pl
}

Submitted 20 Oct 2006

\begin{abstract}
In the times of unification of cultural patterns the art in public areas takes on a very responsible role - creating cognitive map and emphasizing identity of the place. Valuable architectural and sculpture monuments take deserved top position in creating unique townscape. But not only spectacular buildings create the image of the city, sometimes inconspicuous sculptures become city symbols. The subject of research conveyed by the author in Poznan was the quality of public areas and possibilities of making them more attractive by introducing monuments and water elements. Autor define the typology of public art objects (considering their function, form and scale) and methodology of lacalization from the city-scale (according to the viewing popularity aspects and rank of the place) to the csale of indyvidual urban interior. The spatial and social role of sculpture in urban area was analized on examples of public places in Poznan.

Keywords: monuments, sculpture, city image creation, identity, Poznań.
\end{abstract}

\section{Visual art objects and identity of the city}

Historic towns owed their uniqueness to deep roots in local tradition. In times of unification of mass building and cultural patterns in the 20th and 19th centuries, art in public areas takes on a very responsible role - creating a cognitive map ${ }^{1}$ and building identity of the place. There is a campaign going on in modern cities about exhibition area between architecture and sculpture, on the one hand, and commercial forms of advertising art, on the other hand. Without depriving advertisements of the name of art we have to emphasize a substantial difference in the content of message and function of these two different forms of visual art. While historically attractive or contemporary architecture and sculpture try to individualize an urban area, emphasizing its uniqueness, history and urban context, advertisement is the art of unification of space, as it conveys the same contents regardless of localization. Where does the boundary between commerce, inevitable globalization and emphasizing identity of the place lies? What is the role of sculpture elements in building the townscape?

\footnotetext{
1 Tolman, E. C. Cognitive Maps... [1]. The idea of mental maps of the city was developed by $\mathrm{K}$. Lynch in „The image of the city" [2].
}

Valuable architectural and sculpture monuments take deserved top position in creating the image of the city. On the other hand, icons of contemporary architecture emerge numerously, and soon become the aim of cultural tourism. The 20th and 19th centuries abound in spectacular examples of sculptural architectural works which become unique landmarks in townscapes, such as architecture of Frank O. Gehry (e g: Guggenheim Museum, Bilbao, Spain), Steven Holl, Santiago Calatrava, Peter Eisenman (e g: Memorial to the murdered Jews in Europe), Renzo Piano, Herzog \& de Meuron group and others. The works of famous architects can now be found in every part of the global village. However, not all of them can discover and transform local esthetic values into the art language. The example of art which goes back to the roots of the place where it originated is e g work of Renzo Piano - the master of urban context (e g: New Metropolis in Amsterdam, Cultural Centre in Noumea-New Caledonia) or intellectual architecture of Daniel Liberskind.

Not only spectacular buildings create the image of the city, sometimes inconspicuous sculptures become city symbols and important elements of its identity, such as Poznan's famous goats symbol, Mermaid in Copenhagen 

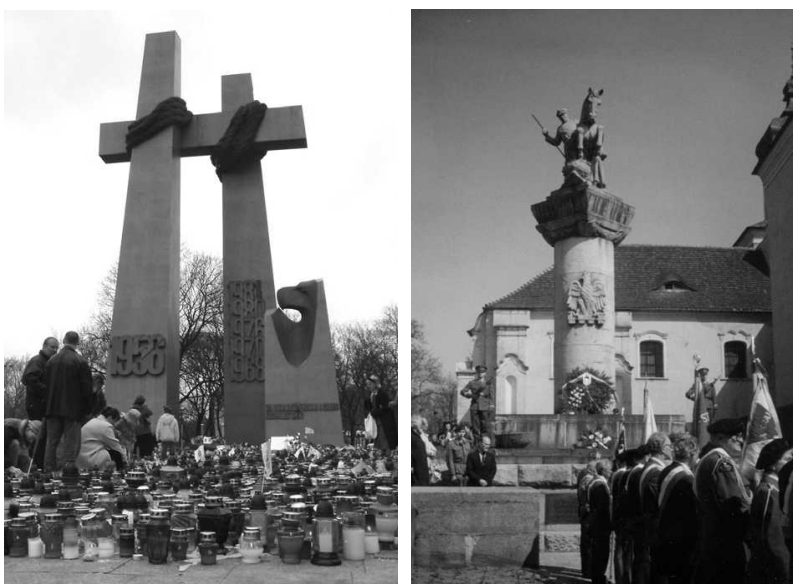

Fig 1. Monument of Victims of a demonstration on 28 June 1956 (Photo by R. Binek) [3]

Fig 2. Monument of 15th Poznan Uhlans Regiment (Photo by author)

and Warsaw or Mannekin Pis in Brussels. This famous statue of a little boy is a perfect representative of the irreverent Belgian humor and the unique Brussels icon.

The function of social integrity of monuments, especially those commemorating historical events and characters, is extremely important. Collective participation in commemoration events builds the feeling of integrity based on cultural membership, historical consciousness and social bonds resulting from common moral values. Decisive historical changes of ideology result in demonstrations and "pulling down monuments", which is a kind of collective manifesto integrating its participants as well.

Thanks to its unique form objects of visual art are tags of city spatial structure. Some of them are dominant, others are only accents in an urban interior. Some carry historical message, others intrigue by modern form, arising admiration or consternation, nevertheless, they individualize the area becoming landmarks, which may arise as an important anchor-points on mental maps of inhabitants.

\section{Typology of sculpture and water elements as urban details}

From the perspective of artistic composition the typology of sculptural objects is considerably wider than the one presented below (Table 1). For the purpose of analysis, several different types of objects were singled out. They differ in the manner of placing, compositional values, function, scale and their social role. Typology was illustrated by examples of existing monuments and sculptures in Poznan.
Table 1. Determination of type of object

\begin{tabular}{|c|c|}
\hline \multirow{3}{*}{$\begin{array}{l}\text { O } \\
\frac{\mathrm{I}}{\mathrm{O}} \\
\frac{\pi}{0}\end{array}$} & directed at one side, two sides or multi side \\
\hline & available, unavailable, penetrative \\
\hline & culminating, leading, closing, framing \\
\hline \multirow{3}{*}{$\begin{array}{l}\bar{d} \\
\stackrel{0}{0} \\
\text { O } \\
\dot{<}\end{array}$} & integrated with water element \\
\hline & integrated with building \\
\hline & freestanding, integrated with square (or not) \\
\hline \multirow{7}{*}{ 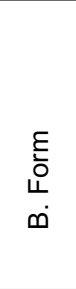 } & permanent or temporary exhibition \\
\hline & one-object, multi-object \\
\hline & compact, diffused, transparent \\
\hline & vertical, horizontal, spherical \\
\hline & abstract, realistic, transformed \\
\hline & static, dynamic \\
\hline & sacral, secular \\
\hline \multirow{7}{*}{ 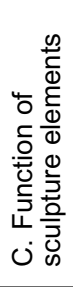 } & culture building \\
\hline & compositional, ornamental, \\
\hline & commemorative, enabling gatherings (or not) \\
\hline & informative \\
\hline & advertising \\
\hline & entertaining \\
\hline & integrating etc. \\
\hline \multirow{6}{*}{ 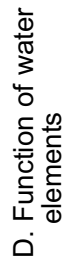 } & $\begin{array}{l}\text { composition, decoration, used for foreground or } \\
\text { background exposition }\end{array}$ \\
\hline & serving active or passive entertainment \\
\hline & retention \\
\hline & biological \\
\hline & microclimatic \\
\hline & utilitarian (e.g. water source) \\
\hline \multirow{6}{*}{ 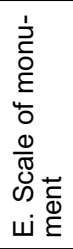 } & Estimated size of vertical lump \\
\hline & $\mathrm{XL} \quad$ Lover $6 \mathrm{~m}$ \\
\hline & L $4-6 \mathrm{~m}$ \\
\hline & M 2-4 m \\
\hline & $\mathrm{S} 1-2 \mathrm{~m}$ \\
\hline & XS up to $1 \mathrm{~m}$ \\
\hline
\end{tabular}

\section{Sculptural landscape of Poznan - analysis of existing sculpture forms}

The presence of sculptural elements in Poznan is noticeable at every level of perception: from panorama, which is dominated by baroque domes of church towers, through huge sculpture compositions organizing space of squares and streets, sculptures on human-size scale familiar to pedestrians, to architectural details. Examples of monuments and sculptures in Poznan are given in Figs 1-13.

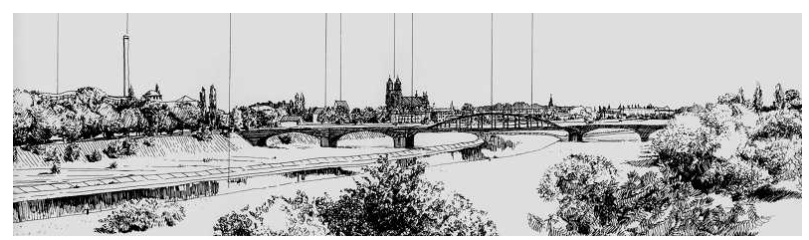

Fig 3. Poznan landscape seen from Queen Jadwiga Bridge. Studio elaboration for Ostrow Tumski (by arch M. Fikus, Poznan, 2004) 
a Large sculpture compositions enabling gatherings

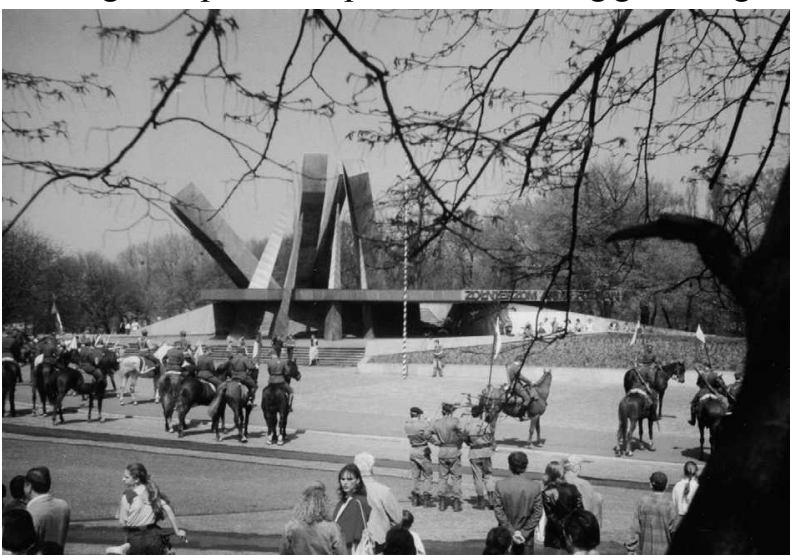

Fig 4. Poznan Army Monument by H. Rodzińska (Photo by author)

Location: multi-sided, available, penetrative, freestanding object; Form: multi-object composition, compact, dynamic, abstract, symbolic; Function: cultural building, commemorative, integrating, compositional; Scale: $X L$

c Sculpture form integrated with water (examples - fountains on Old Market Square in Poznan)
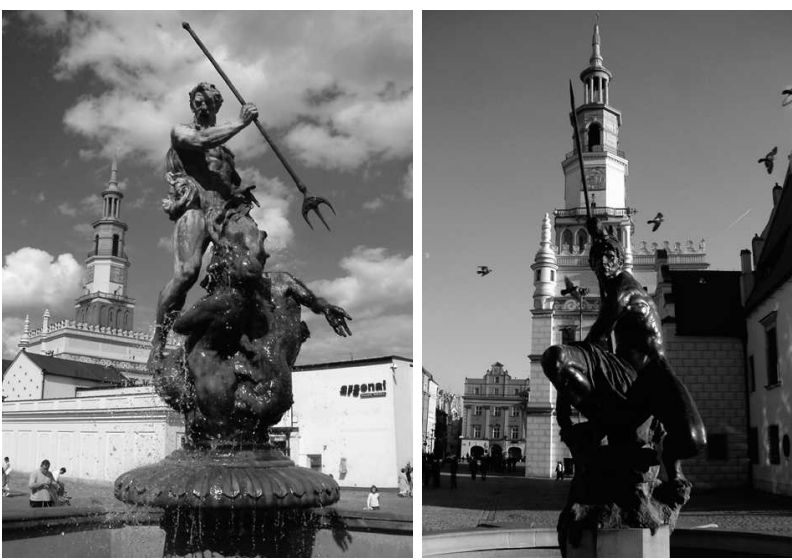

Fig 7. Fountain of Neptune (Photo by R. Binek) [3]

Fig 8. Fountain of Mars (Photo by R. Binek) [3]

Location: multi-sided, available, interior connection, permanent exhibition, Form: single object, compact, vertical, realistic, dynamic by water movement, secular (mythological motives); Function: cultural building, compositional, utilitarian, microclimatic, Scale: M

On the turn of the 19th and 20th centuries Poznan was a city famous of its fountains and monuments. Part of them after war destructions were restored or copied just in the 21 st century (e g fountains on Old Market Square).

d Sculpture form integrated with building

Fig 11. Great Theatre (Photo by P. Skórnicki) [5]

Location: multi-sided, available, integrated with building, framing the entrance; Form: multi-object, compact, vertical, static, representative, secular; Function: cultural building, compositional, ornamental; Scale: M
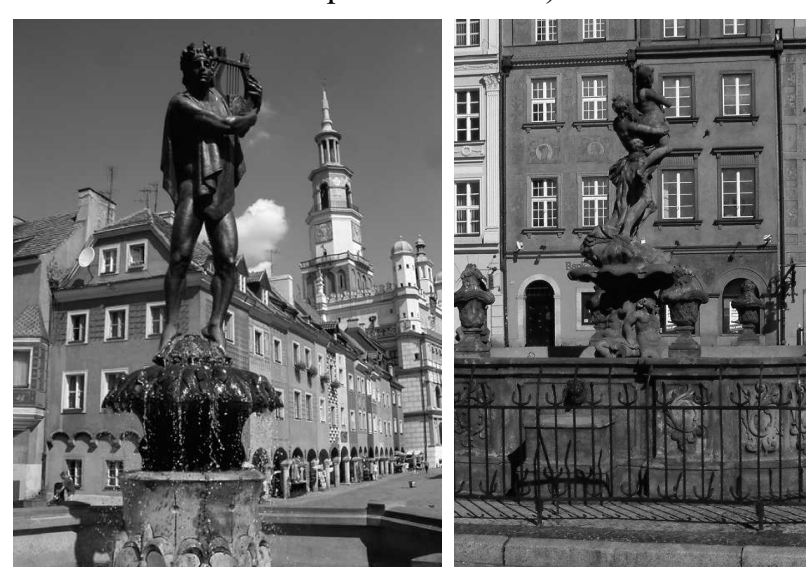

Fig 9. Fountain of Apollo (Photo by R. Binek) [3]

Fig 10. Fountain of Proserpine (Photo by R. Binek) [3]

b Human-size street sculptures

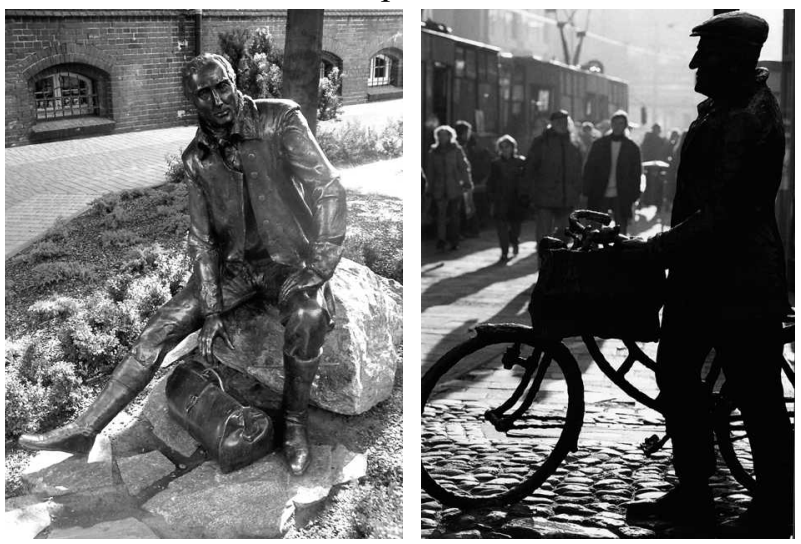

Fig 5. Monument of K. Marcinkowski in front of "Marcinek" (Photo by R. Binek) [3]

Fig 6. Monument of "Old Marych" on Polwiejska Street (Photo by P. Skórnicki [4]

Pulti-sided, available, freestanding object; Form: onebuilding, integrating, commemorative, educational, compositional; Scale: M

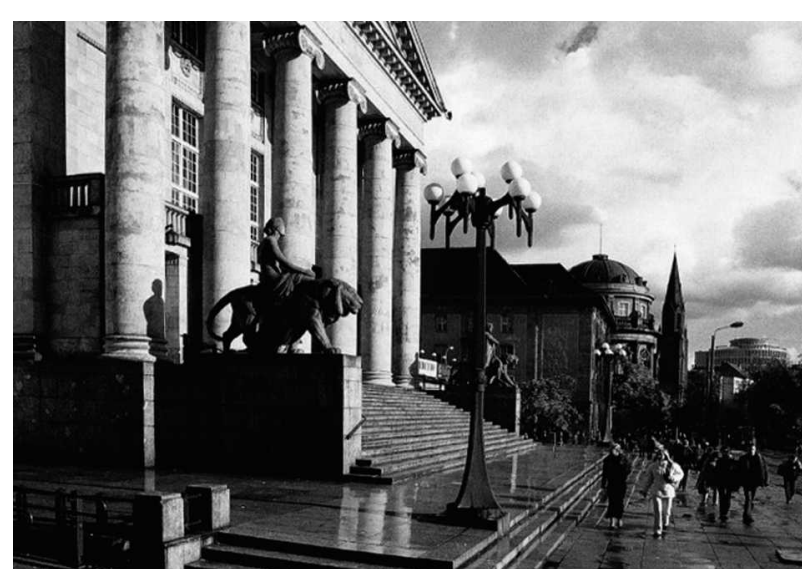


An excellent example of creating uniqueness of a place in park landscape is sculpture exhibition of Magdalena Abakanowicz in Citadel. It is deeply rooted in history which emphasizes identity of the place of memory having a modern form at the same time.

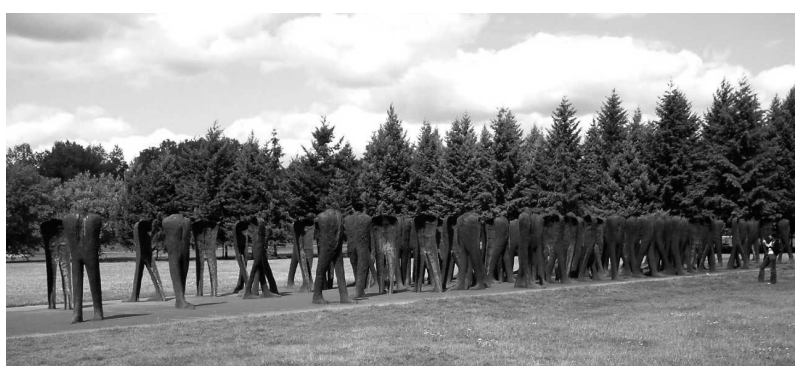

Fig 12. Unrecognized by Magdalena Abakanowicz in Citadel (Photo by R. Binek) [3]

Location: multi-sided, available, penetrative, freestanding object;

Form: multi-object composition, diffused, static, transformed, secular; Function: cultural building, integrating, commemorative, educational, compositional; Scale: M

Contrary to permanent monuments, temporary sculpture exhibitions and installations in an urban area, as short-time but concentrated events of great cultural expession, can have even a bigger influence on inhabitants' minds and create a sense of cultural identity and unique spirit of the place ${ }^{2}$ (e g I. Mitoraj's sculpture exibition at Old Market Square, J. Kopeć's instalation at Freedom Square, exhibitions in front of "Castle" Cultural Center, in Citadel or at Malta Lake).

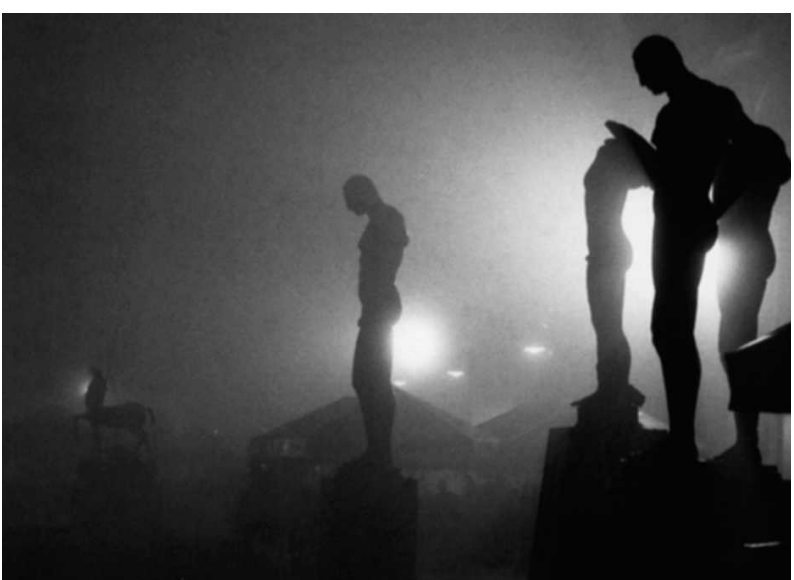

Fig 13. I. Mitoraj's sculpture exhibition on Old Market Square in Poznan, 2003 (Photo by P. Skórnicki) [4]

Location: multi-sided, available, penetrative, freestanding objects; Form: one and multi-object compositions, diffused, static, transformed, secular; Function: cultural building, integrating, compositional, ornamental; Scale: M-L

\footnotetext{
${ }^{2}$ International Sculpture Triennale "Sensitivity" - Poznan, 2006 takes place in the Cultural Center "Zamek" in Poznan, on 10-31 October 2006.
}

The number of atractive public spaces in Poznan allows to expose different objects and sculpture compositions, to rebuild the old splendour of Poznan's sculpture landscape and to bring on new cultural values.

\section{Strategy of the Royal-Imperial Track - city image creation in Poznań}

Creation of the image of the city is a process going on at many levels (cultural, economic, social, political, etc). The problems discussed in the paper refer mostly to spatial aspects connected with townscape and the quality of public areas. Renovation of these areas is a part of the Program "The Royal-Imperial Track in Poznan"3, which is an element of National Strategy of Cultural Development 2004-2013, which plans creating integrated national tourist attractions (city \& culture) in the most important Polish cities. The main aim of this Program is protection and promotion of cultural heritage, in particular renovation of historic objects. The means to achieve this goal in free-economy market is combining material and non-material cultural heritage of Poznan with an economic sphere, in this case - tourism. Poznan is, undoubtedly, a very attractive city for business tourism thanks to its location between Berlin and Warsaw and Poznan International Fair. Realization of the Program will create a great opportunity for cultural and city tourism development. Tract gives possibility to expose clear stages of spatial and architectural development of the city (Ostrow Tumski settlment, the 19th century Town Center, the beginning of the 20th century: Castle District, Jezyce, Lazarz, Wilda, mansion district in Solacz park), diversity of architectural styles (from roman style to Art Nouveau), multi national cultural threads in the city history as well as a rich cultural offer.

Monuments, as attractive spatial forms connected with the history of the city and its inhabitants, can constitute landmarks of the main tourist routes, helping to build a sense of identity, spreading cultural values and knowledge about the city.

\footnotetext{
3 look: Strategy of Development of National Tourism Product "The Royal-Imperial Track in Poznan", Poznan, 2005 [6]. The concept of "The Royal-Imperial Track" was created by Regional Institute of Research and Documentation of Ancient Monuments in Poznan, under management of Dorota Matyaszczyk. Strategy of Development of National Tourism Product „The Royal-Imperial Track in Poznan”-Project Group of Polish Agency for Tourism Development S. A. and Res Management.
} 


\section{Methodology of locating monuments in public areas of the city}

The subject of research conveyed by the author in Poznan was the quality of public areas and possibilities of making them more attractive by introducing monuments and water elements. One of the first research tasks was creating typology of objects and stating their role in functional and spatial structure of the city. The parallel task was connected with looking for the main areas of the city image creation.

Searching for optimal locations of various types of sculpture objects in the city was divided into III stages:

I - determining areas of the city with the highest viewing popularity (Fig 14) and rank of the place (Fig 15) on the basis of graphical method, choosing public places in certain areas and their preliminary selection on the basis of multi-criterion analysis and SWOT.

II - analysis and evaluation of the quality of urban interior and exhibition capabilities for chosen public sites in Poznan, taking into consideration historic and cultural, compositional, architectural and esthetical, functional and communicative values.

III - creating functional and compositional guidelines for localization of monuments and water elements, determining their type and location (Fig 16).

\subsection{Stage I: analysis and evaluation of functional and spatial structure of the city with respect to possibilities of locating monuments and water elements according to basic criteria - viewing popularity and rank of the place}

Analysis of functional and spatial structure on the scale of the whole city ${ }^{4}$ allowed us to single out areas with the highest viewing popularity - communication frames of the city and radiant links. Due to a high concentration of pedestrians and location of the main areas of the city image creation, the analysis was narrowed to communication frame II with a detailed analysis of the city centre. The main criteria and sub-criteria mentioned in Table 2 describe particular levels of graphical analysis.

Conclusion: on the basis of functional and spatial analysis of the city center and districts within communication frame II, the most desirable zones and places for locating monuments were distinguished. These are the ones:

\footnotetext{
${ }^{4}$ Research was based on authors maethodology and Studium of Delimitations and Directions of Spatial Development of Poznań 2006 [7].
}

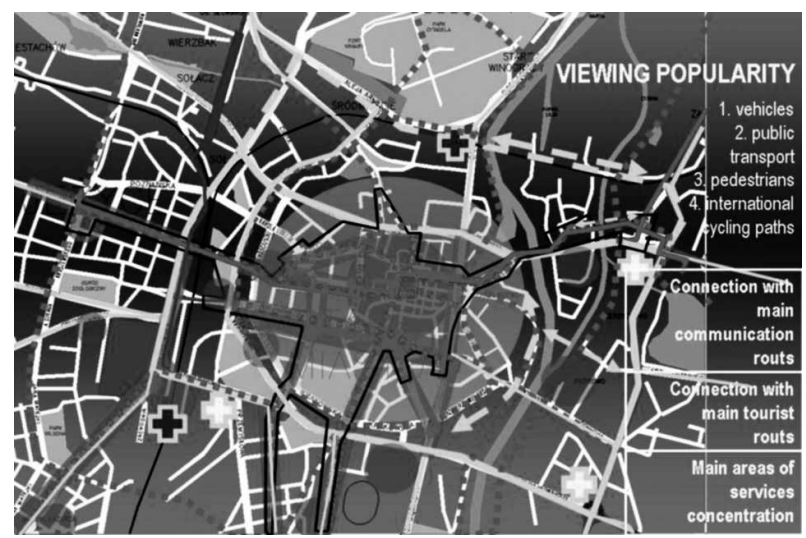

Fig 14. Poznan - areas of the highest viewing popularity in the city center (synthesis)

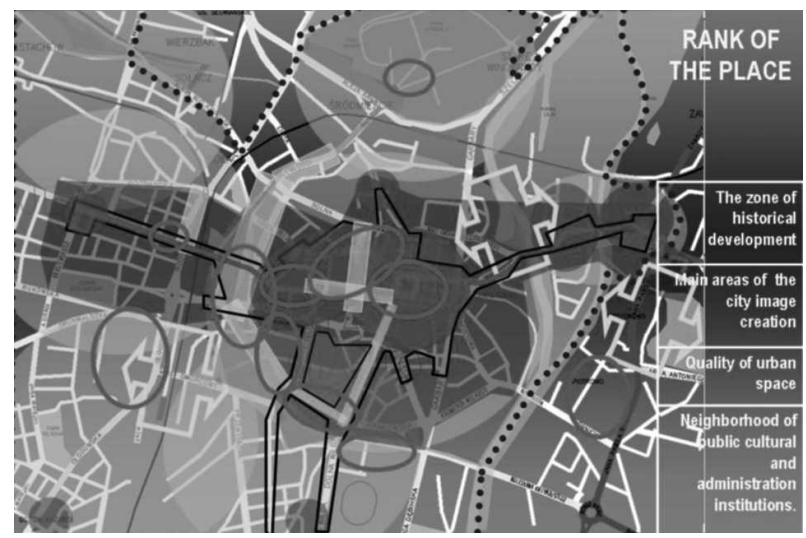

Fig 15. Poznan - areas of the highest rank of the place in the city center (synthesis)

- of the highest cultural value (Ostrow Tumski, Srodka, Old Market Square, Castle District, City "Lounge": Stubben's Ring, Marcinkowski ave, Wolnosci sq, Roosvelta str, Polwiejska str, etc);

- of the highest viewing popularity (communication frames and main roads, nodes of public transport, bus/train stations, "city gates", pedestrian routes: main walking and shopping streets, Poznan International Fair, university campuses;

- strategic for tourism development (The RoyalImperial Track, Piastowski Route) and recreation (Malta, Warta River bank, Citadel, Solacz).

\subsection{Choice of areas for localization of potential monuments and water elements}

In the zones of the highest importance about 60 public places were indicated - streets, squares, parks, river banks, etc - and were subject to preliminary selection. 


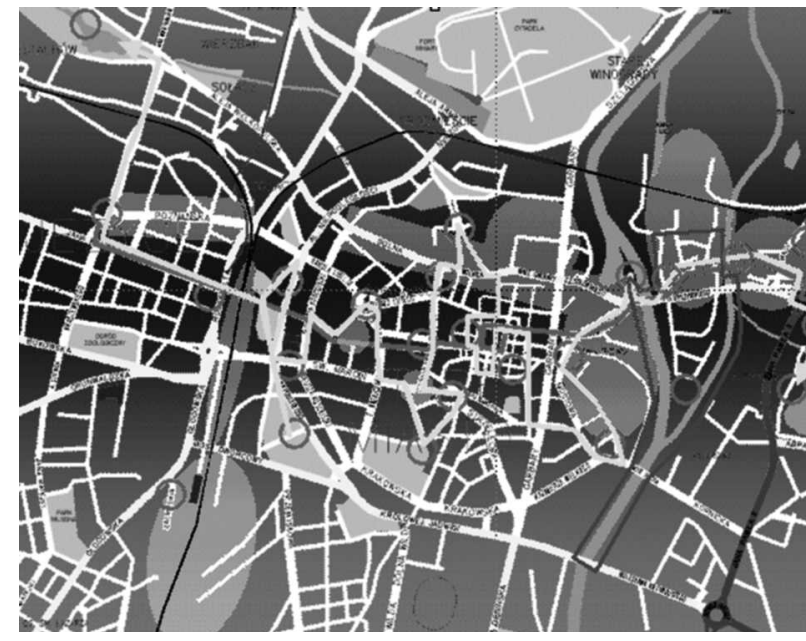

Fig 16. Poznan - wounded spaces (yellow areas) and chosen public places for locating monuments (red circles) in the city center (synthesis)

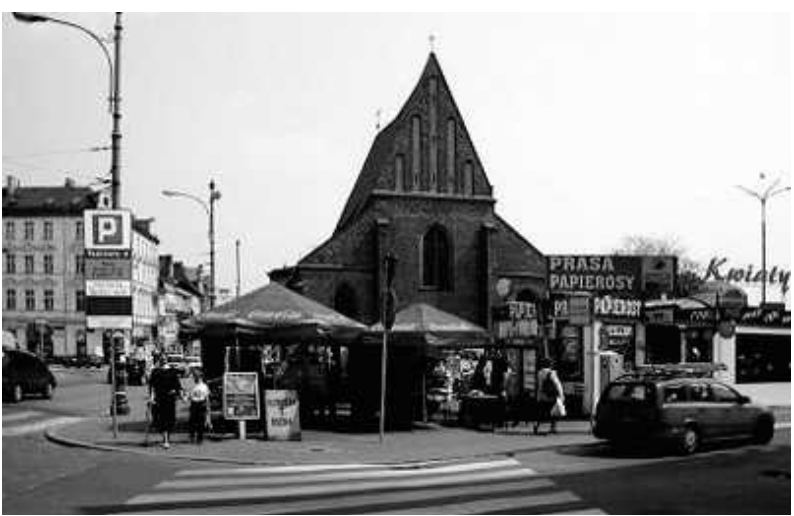

Fig 17. St Marcin's Church. The square in front of the church on the focal point of axis of Marcinkowski Avenue and St Marcin Street occupied by parking places and temporary, substandard elements. The walls of urban interior remain undefined

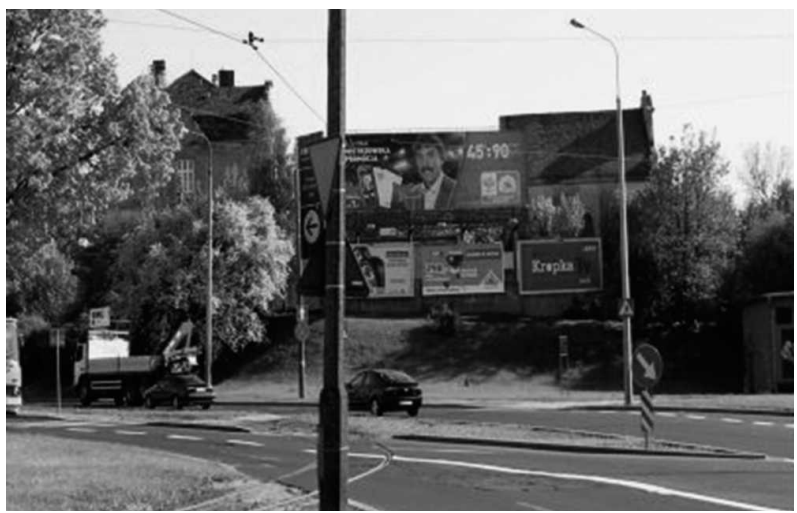

Fig 18. Zawady Street - important places ocupied by advertising art. Blocked view of Śródka with its 17 th century monastery and St Kazimierz Church
The final effect of stage I of the analysis is the Catalogue of Public Places in Poznan, containing information about all individual public places with the description of their location, neighborhood, spatial layout and function, short SWOT analysis, and preliminary estimation of capabilities for locating monuments and water elements.

Several places of strategic localization, high rank and utility were singled out on the basis of multi-criteria analysis.

Finally, the following conclusions can be drawn: Poznań has got many perfect public areas for locating monuments of social and landscape function, e g parks and squares around Ring Stubbena could be used for locating sculpture objects of commemorative, compositional and decorative functions; squares in the city center, e g Wolności Square and Wiosny Ludów Square which enable organizing mass events could be used for locating objects of integrating, commemorative and educational function connected with the history of Poznan. There are also several places of high importance in the very center of the city, i e the region of Estkowskiego Street and Garbary Street, the square in front of St Marcin's Church (Fig 17) or the area in front of the Polish Theatre, the potential of which for exhibitions is not used due to lack of decision concerning the final spatial shape of the urban interior.

The center of Poznan is not overloaded with large advertising elements, nevertheless, the disadvantage of the visual esthetic structure of the greater part of the city center is its "island character". The axis of the Track combines many visually and culturally attractive elements, which sometimes create isolated " islands of beauty" connected by less attractive routs. Some places, which are important key elements of the Track, remain neglected. The lack of defined form of interior makes it impossible to give them final spatial layout and locate urban detail. Therefore, there is a need for town structures renewal on large scale and creating contiuous visually attractive passages.

It is significant that along all communication frames places of the best spatial exposure are occupied by advertising boards (Fig 18) which depreciate architectural values of the place (not only by aggressive colors but also by covering valuable views). In particular in communication nodes, where frame II crosses the main rail roads leading to the center, it would be advisable to substitute advertising objects with sculptures in order to emphasize and individualize entrances to the city. Due to perceptive capabilities of drivers and the scale 
Table 2. Multi-criteria analysis

\begin{tabular}{|c|c|c|c|}
\hline $\begin{array}{l}\text { Basic } \\
\text { criteria }\end{array}$ & Sub-criteria & Elements of funcional-spatial structure of the city & $\begin{array}{l}\text { Ratio of im- } \\
\text { portance }\end{array}$ \\
\hline \multirow{9}{*}{ 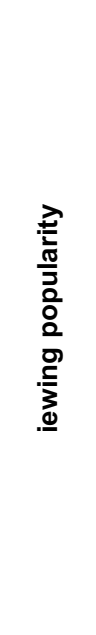 } & \multirow{4}{*}{$\begin{array}{l}\text { Connection with main } \\
\text { communication routes }\end{array}$} & 1. vehicles (communication frames and radiant connections) & 01.1. \\
\hline & & 2. public transport- train, bus and tram stations & O1.2. \\
\hline & & 3. pedestrians ( high streets, shopping routes) & O1.3. \\
\hline & & 4. international cycling paths & O1.4. \\
\hline & \multirow{2}{*}{$\begin{array}{l}\text { Connection with main } \\
\text { tourist routes }\end{array}$} & 1. The Royal-Imperial Track & 0.2 .1 \\
\hline & & 2. Piastowski route & O2.2. \\
\hline & \multirow{3}{*}{$\begin{array}{l}\text { Main areas of service } \\
\text { concentration }\end{array}$} & $\begin{array}{l}\text { 1. the city center (Old Market Square, Półwiejska, Śt. Marcin, } 23 \\
\text { lutego, Ratajczaka, etc) }\end{array}$ & O.3.1 \\
\hline & & $\begin{array}{l}\text { 2. centers of districts (Jeżyce, Łazarz, Górczyn, Wilda) and main } \\
\text { shopping streets }\end{array}$ & O.3.2. \\
\hline & & 3. PIF, university campuses & 0.3 .3 \\
\hline \multirow{12}{*}{ 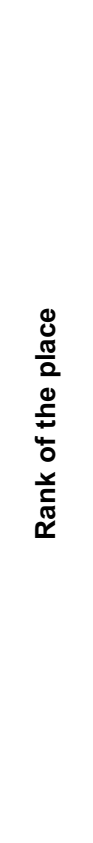 } & \multirow{3}{*}{$\begin{array}{l}\text { Zone of historical } \\
\text { development }\end{array}$} & 1. the city center & R 1.1. \\
\hline & & 2. 19th/20th century districts (Jeżyce, Łazarz, Górczyn, Wilda) & R 1.2 . \\
\hline & & 3. remaining areas (20th century) & $\mathrm{R} 1.3$. \\
\hline & \multirow{3}{*}{$\begin{array}{l}\text { Main areas of the city } \\
\text { image creation }\end{array}$} & 1. axis of The Royal-Imperial Track and zone of influence & R 2.1 . \\
\hline & & $\begin{array}{l}\text { 2. the city "gates" (Central Station-PIF, river harbour-historic center, } \\
\text { Malta-sport center, airport) }\end{array}$ & R 2.2 . \\
\hline & & 3. the city's "lounge" ( Niepodległości avenue, Roosvelta str, etc) & R 2.3. \\
\hline & \multirow{3}{*}{ Quality of urban space } & $\begin{array}{l}\text { 1. zones of urban historical urban structures and city parks } \\
\text { under law protection }\end{array}$ & R 3.1. \\
\hline & & 2. high concentration of antique buildings & R 3.2 . \\
\hline & & 3. areas of exceptional townscape and landscape values & R 3.3. \\
\hline & \multirow{3}{*}{$\begin{array}{l}\text { Neighborhood of public } \\
\text { cultural and administration } \\
\text { institutions }\end{array}$} & 1. of international, national and regional importance & R 4.1. \\
\hline & & 2. of city importance & R 4.2 . \\
\hline & & 3. of district importance & $\mathrm{R} 4.3$. \\
\hline
\end{tabular}

of communicative infrastructure large-scale monuments are recommended.

\subsection{Stage II: evaluation of quality of urban inte- rior and exhibition capabilities of chosen public places in Poznan according to detailed criteria}

Each public place described in the "Catalogue" was analysed from the point of view of their exhibition values and evaluated according to all the aspects of multi-criteria analysis. SWOT analysis allowed to find out strong and week sides of localization as well as opportunities and traps of potential location of monuments and water elements. Chosen public places (with the best exhibition values) were subject to spatial and functional analysis according to detailed criteria described in Table 3. Special attention was given to exhibition and compositional values, complexity of spatial structures, quality of architecture as well as historic and cultural background of each place and social integrating capabilities. 
Table 3. Criteria for spatial and functional analysis of chosen public spaces

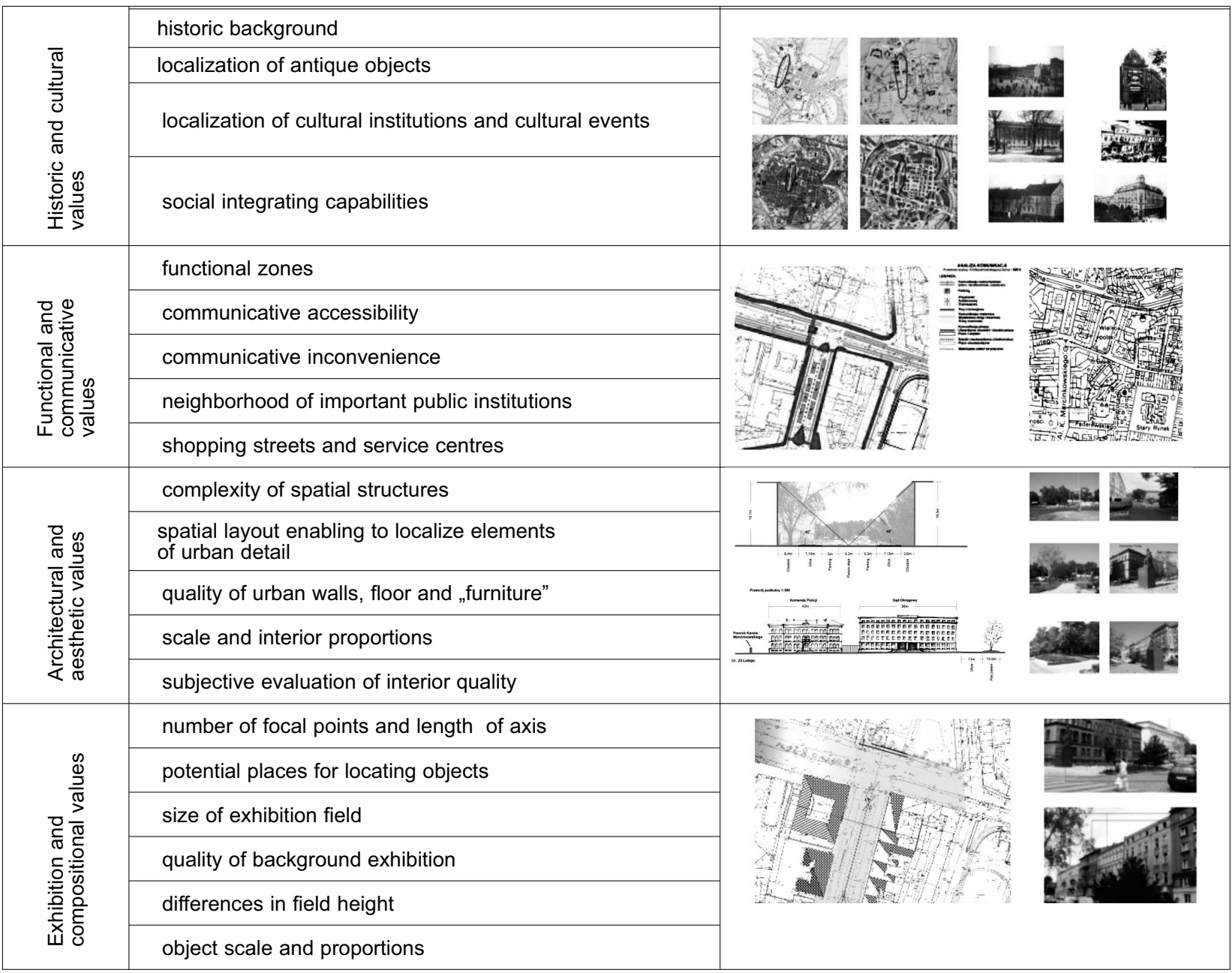

Table 4. Functional and spatial guidelines for locating monuments and urban interior arrangement

\begin{tabular}{|c|c|c|}
\hline \multirow{7}{*}{ 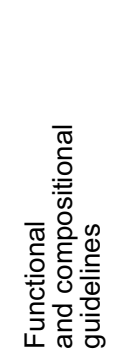 } & places for locating monuments and water elements & \multirow{6}{*}{ 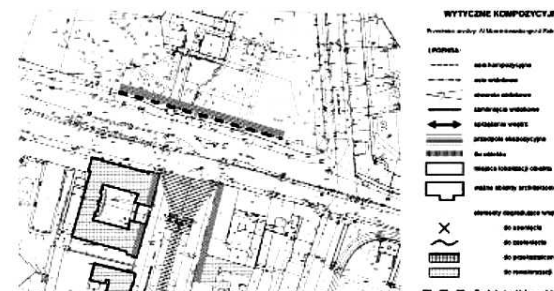 } \\
\hline & functional and communicative layout & \\
\hline & object scale and proportions & \\
\hline & exhibition foreground and background arrangement & \\
\hline & arrangement and type of pavement & \\
\hline & urban wall arrangement & \\
\hline & greenery composition layout & \\
\hline 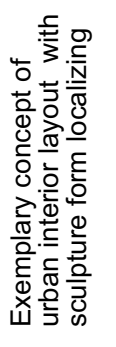 & $\begin{array}{l}\text { The range of analysis, guidlines and concept is } \\
\text { presented on example of K. Marcinkowskiego } \\
\text { Avenue (authors: } \downarrow \text {. Małysz i O. Przygońska, under } \\
\text { supervision of A. Januchta-Szostak). }\end{array}$ & 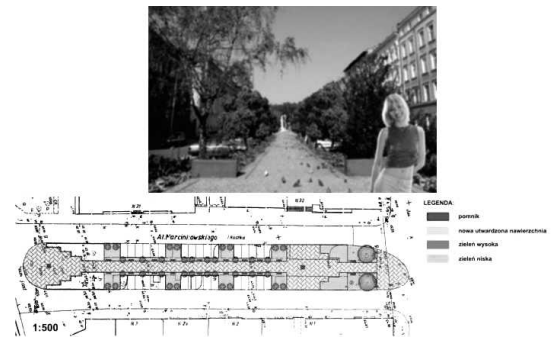 \\
\hline
\end{tabular}




\subsection{Stage III: functional and compositional guidelines for localizing monuments and water elements and exemplary concept of urban interior layout with sculpture form localizing}

Functional and spatial guidelines for locating monuments and urban interior arrangement are the basis for an architectural concept leading to the Master Plan (Table 4). The composition definition of the most suitable type of a monument and water elements for every place is necessary to establish conditions for architectural or artistic context for the spatial form of public art elements.

Exemplary concepts of locating sculptural and water forms in urban interiors are shown in Figs 19-22.
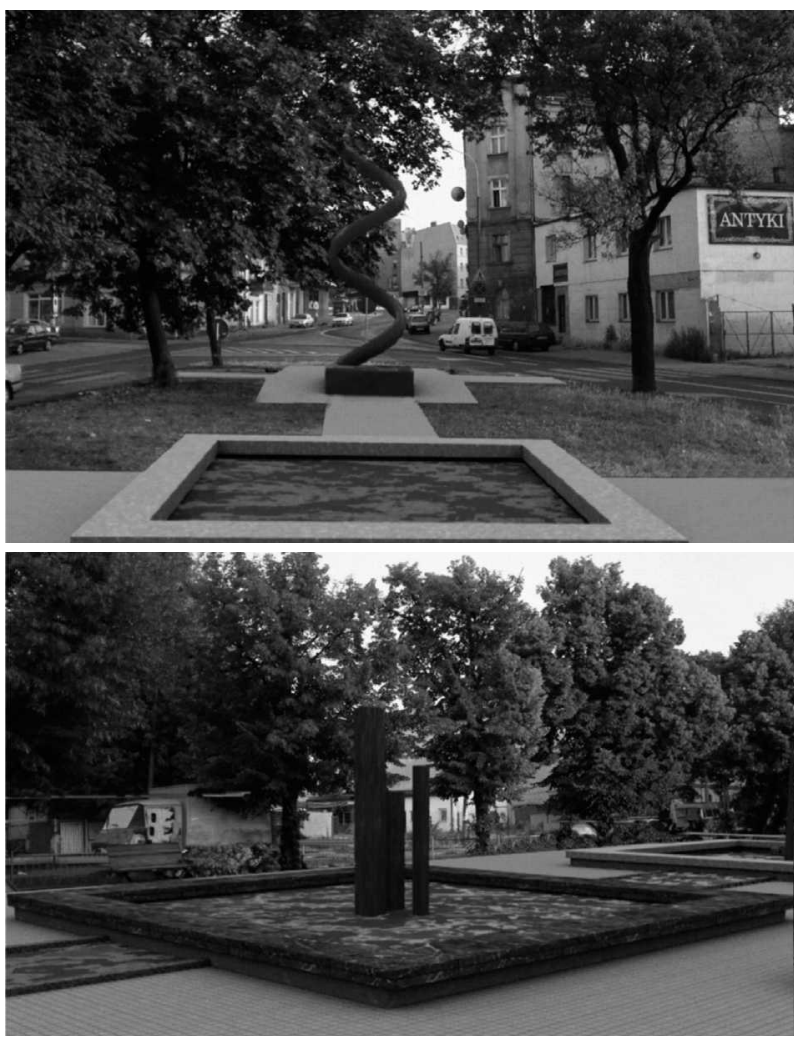

Fig 19, 20. Kościelna street in Poznań (Authors: K. Krupińska, B. Ceglarska under supervision of $\operatorname{Dr}$ A. Januchta-Szostak)

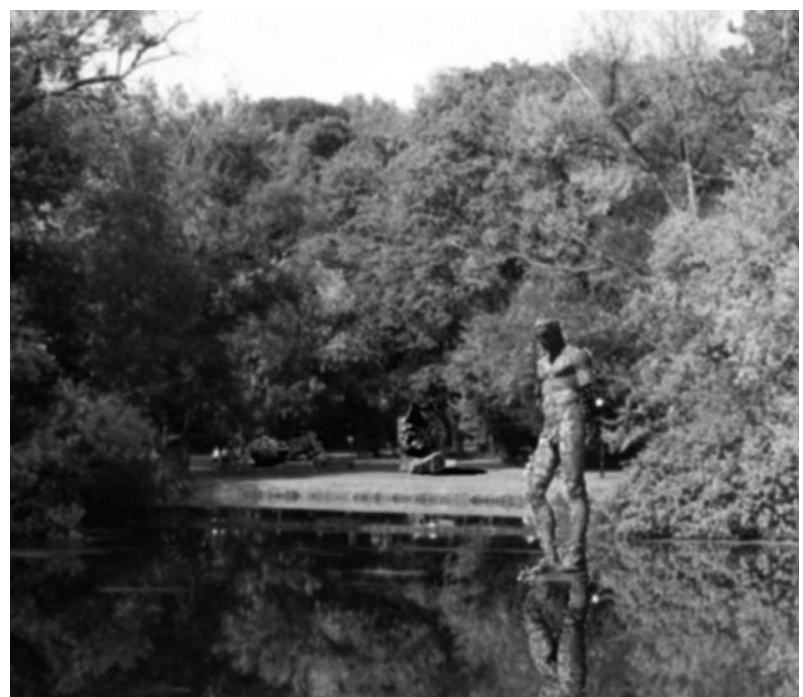

Fig 22. Solacz Park in Poznań (Author: L. Chlasta under supervision of dr A. Januchta-Szostak)

The examples illustrate different possibilities of using water as a foreground for sculpture exhibition.

\section{Summarizing}

Localization, form and function of the objects of visual art play an important role in the process of raising attractiveness of public spaces and making townscape more individual. It can also be a crucial element of visual information system in the town. It lies in the hands of architects, town-planners, sculptors and city authorities to take advantage of this potential to improve the quality of townscape and build up identity of domain.

Visual art inspires our senses and minds. Monuments are bridges between the future and the past as they are built by contemporary societies for future generations to commemorate those who have already departed from this world.

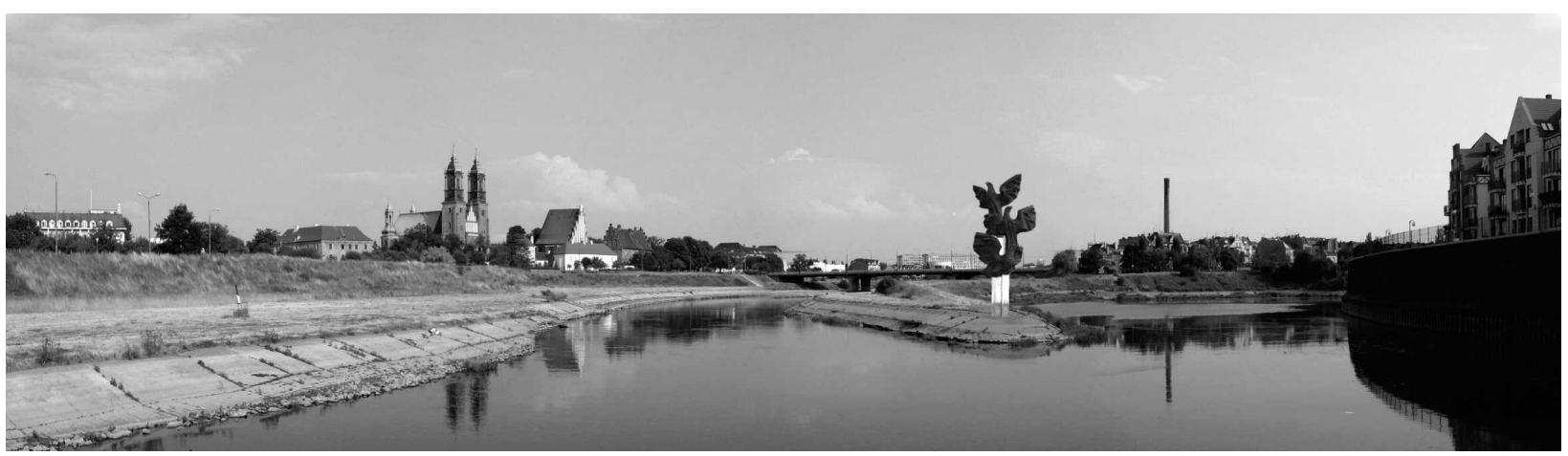

Fig 21. City gate - river harbour near Ostrów Tumski (Author: M. Dajerling under supervision of Dr A. Januchta-Szostak) 
The author hopes that the objects of visual art, both monumental and those less remarkable but closely connected with the identity of the city, will start to appear in large numbers in public areas of Poznań, becoming essential landmarks characteristic of townscape in both inhabitants' and tourists' consciousness.

\section{References}

1. TOLMAN, E. C. Cognitive Maps in Rats and Man. Psychological Review, 1948, 55, p. 189-208.

2. LYNCH, K. The image of the city. Cambridge: MIT Press, 1960.

3. http://commons.wikimedia.org/wiki

4. BUDREWICZ, O.; SKÓRNICKI, P. Poznań. BOSZ Polska. Olszanica, 2004.

5. http:/www.city.poznan.pl

6. http://mim.man.poznan.pl

7. Studium Uwarunkowań I Kierunków Zagospodarowania Przestrzennego Poznania 2006. Mpu Poznań, 2006.

\section{VIZUALINIO MENO LOKALIZACIJOS VIEŠOSIOSE ERDVĖSE METODOLOGIJA POZNANĖS PAVYZDŽIU}

\section{A. Januchta-Szostak}

Santrauka. Vienodẻjant kultūriniams kontekstams viešųjų erdvių menas igyja ypatingą ir labai svarbią reikšmę kaip atpažinimo elementais atskleidžiantis ir pabrežiantis vietos identitetą. Vertingi architektūriniai ir skulptūriniai elementai tampa svarbiausiais unikalių miestovaizdžių formantais. Tačiau ne tik ịspūdingi statiniai kuria miesto vaizdą. Kartais niekuo neišsiskiriančios, vos pastebimos skulptūros tampa miesto simboliais. Tyrimo, atlikto Poznanès mokslininkès, tema yra viešujų erdvių kokybè ir galimybè padidinti jų patrauklumą meno kūriniais ir vandens elementais. Autorè apibrèžè viešojo meno objektų tipologiją, ịvertindama jų paskirtị, formą ir mastelį, ir lokalizacijos metodiką nuo viso miesto masto iki mažiausiojo mastelio nominalių erdvių, ịvertindama apžvalgos populiarumą ir vietos kategoriją. Poznanès pavyzdžiu išanalizuotas tiek erdvinis, tiek visuomeninis miesto skulptūrų vaidmuo.

Reikšminiai žodžiai: monumentai, skulptūros, miesto ịvaizdžio kūrimas, identitetas, Poznanè.

\section{ANNA JANUCHTA-SZOSTAK}

Dr, eng arch, adjunct at Institute of Architecture and Physical Planning, Faculty of Architecture, Poznan University of Technology, ul. Nieszawska 13C, 61-021 Poznań, Poland. E-mail: Anna.Januchta-Szostak@put.poznan.pl

Employment: Faculty co-ordinator for students exchange and international relations, 2000-2002; v-Dean of Faculty of Architecture PUT, 2002-2005. Teaching: theory of recreational architecture (lectures), design of recreational architecture, rural architectural design, landscape architecture, planting design, planning of communal land use, research studio. Conferences: participant of over 10 conferences. Publications: author of 10 scientific publications. Projects: author and co-author of 24 projects of architectural design, townplanning and landscape architecture. Research interests: recreational architecture (equestrian centres), water in spatial planning, urbanism and architecture, town-planning, landscaping and planting design. 